\title{
Discussion on the Transformation Strategy of the General Welfare Service Ministry of MND-The Case of Taiwan
}

\author{
Jui-Lung Chen ${ }^{1} \&$ Jun-Ming Hong ${ }^{1}$ \\ ${ }^{1}$ Department of Business Administration, National Chin-Yi University of Technology, Taiwan, R.O.C \\ Correspondence: Jui-Lung Chen, Department of Business Administration, National Chin-Yi University of \\ Technology, No.57, Sec. 2, Zhongshan Rd., Taiping Dist., Taichung 41170, Taiwan, R.O.C. E-mail: \\ leonchen@ncut.edu.tw
}

Received: July 23, 2021

Accepted: August 25, $2021 \quad$ Online Published: September 18, 2021

doi:10.5539/ijbm.v16n10p95

URL: https://doi.org/10.5539/ijbm.v16n10p95

\begin{abstract}
The Army Welfare Service (AWS) has been one of the important policies promoted vigorously by the R.O.C. (Taiwan) government. With the full implementation of the Mercenary System, how to improve the quality of welfare work will resonate with all the military officers and soldiers of the National Army, and its effect will directly affect the effectiveness of recruiting. Among them, the welfare stations and military camp stations created by the General Welfare Service Ministry of the Ministry of National Defense (MND) R.O.C. in various regions are the only service organizations in the National Army that can directly benefit military officers, soldiers and their families. In the face of the rapid growth of retail channel operators and changes in the overall sales pattern in the current market, how should the General Welfare Service Ministry of MND's business model transform to meet the needs of consumers on the product side and the shopping model. This research explores the literature to understand how the General Welfare Service Ministry of MND R.O.C. can effectively transform its business model under the prerequisite of limited sales objects, so as to adopt more flexible business models and marketing strategies that can resonate with consumers, and ensure product quality and expand service categories at the same time, creating a win-win situation between the General Welfare Service Ministry of MND R.O.C. and consumers.

This study adopts a qualitative research method, and conducts in-depth interviews with three different types of subjects that are closely related to the transformation of the General Welfare Service. It is hoped to explore the value of the research, and provide specific transformation recommendations to be used as a reference for the future decision-making by the General Welfare Service Ministry of MND R.O.C. This study found that in addition to emphasizing product quality and price lower than the average market price, it should also focus on product promotion, and comprehensively upgrade the interior of the store with modern designs to attract young consumers. In addition, through the establishment of the NRA's own brand image, the use of big data to create more diversified promotion methods, the provision of on-line payment consumption options and other active operational transformation measures, it can ensure sustainable operation and continue to benefit service recipients.
\end{abstract}

Keywords: Army Welfare Service (AWS), consumer behavior, marketing strategy

\section{Introduction}

As time changes and public awareness and living standards improve, consumers expect higher level of respect in the aspects of visual perception and service experience than in material needs. Therefore, the traditional business model of retail industry has failed to meet the actual demands of modern consumers. In order to enhance consumer satisfaction, retailers must keep upgrading their business models and related marketing methods to attract consumers and bring them more diversified service. In the competition with peers of the same nature, department stores should find out a way to create business advantages to meet the actual needs of customers, offer them reasonable prices and high-quality service by expanding the content and added value of products, and continue to create consumer value and improve service content to meet consumer expectations, so that they can maintain and increase their market share without declining or being knocked out. In recent years, due to the transformation of the mercenary system, Taiwan National Defense has gradually begun to comprehensively promote the "Three Security Policies", namely "To Secure the Army", "To Secure the Home of Soldiers" and 
"To Secure Family Dependents of Soldiers from Worries". Therefore, General Welfare Service Ministry of MND R.O.C. (GWSM), as the specialized organization in charge of general welfare service, plays an indispensable role in implementing the welfare of officers, soldiers and their families. Established in 1964, GWSM specializes in coordinating the welfare of the National Army. Its related businesses have been playing an important role in promoting the welfare work of the army. Among them, welfare stations scattered around Taiwan and military camp stations are organizations that can directly benefit the consumers (General Welfare Service Ministry of MND R.O.C., 2021).

These stations, except for the military stations that have monopolized the market, are drawn into the competition with other private retailers. Therefore, under the operational pressure of assuming sole responsibility for profits and losses, it deserves further consideration and discussion on how to meet the needs of consumers whose shopping habits have changed, renew the service functions and role of the welfare stations, and be more competitive in product quality, prices, service quality and marketing methods to attract consumers and improve business performance, so that more valuable operation and marketing strategies can be formulated. GWSM, whose consumers are qualified personnel with welfare certificates like officers, soldiers, their dependents, and veterans, is not open to the public. Therefore, its consumer source is limited, which makes it even harder in competition. What's worse, its targeted consumers are also common consumers who can choose shopping places based on personal will. Shopping in GWSM's welfare stations is only one of many options after comparison. In other words, faced with environment where numerous retail channels compete furiously, GWSM, a public retail channel, has to start to transform to conform to the current consumption mode. However, as private retailers alike adopt the same sales promotion but more innovative and flexible marketing methods, GWSM will be bound to struggle to meet today's consumers' demands if it only emphasizes "low price" marketing strategy. If its basic consumers turn to private counterparts, its operation performance will be seriously impacted because of the gradual loss of customers. The promotion activities, the compound business mode and a large amount of advertising and publicizing expenses will relatively influence the operation performance of GWSM. The author worked as senior director of GWSM. During tenure, he realized that the transformation of CWSM must be enforced. Therefore, the purpose of the study is to explore the sustainable transformation management policy in the future, to discuss with the suppliers about how to continue to cooperate to avoid loss and deal with various competitors such as PX Mart, and to discover the impact of competition and cooperation on sustainable operation.

The service industry must keep pace with the times, and keep trying its best to pursue characteristic and quality service. GWSM is both a public organization and an operation center of promoting military welfare. Due to the progress of the times and the organizational adjustment and reform in the military, its operation performance is weaker and weaker. Although it keeps reforming and innovating and studying and making strategies to improve performance, such as enlarging consumer group and utilizing human and financial resources more flexibly, it is constrained by military system and political factors, which is in urgent need to be discussed and dealt with. The study explores how GWSM makes efforts to transform by upholding the core values of "honesty, enthusiasm, and public welfare" and focusing on four aspirations of "improving professional skills of staff, optimizing services by introducing new information equipment system, and having regular education and training to enhance staff professionalism and service quality", "continuously carrying out store transformation plan in response to the trend of modernization of stores and creating a more comfortable shopping environment by making use of diversified products and modern technologies", "promoting self-service stores, which is now being actively discussed to simplify labor and payment methods and hopefully to provide 24-hour service for military officers and soldiers" and "planning exhibition spots in the village of dependents, which means to make sure officers and soldiers could focus on their tasks, GWSM actively cooperates to transform the military villages and sets new stations and takes care of dependents by providing better shopping environment." (General Welfare Service Ministry of MND R.O.C., 2021)

Our ability to be clear about consumers can be improved by understanding the consumer market, consumer buying decisions, and the factors that affect consumer buying behavior (Kotler and Armstrong, 2017). However, nowadays, PX Mart, which was separated from GWSM's predecessor Welfare Center for Soldiers, Civil Servants and Teaching Staff, has monopolized most of the markets, and keeps absorbing GWSM's customers through political and supplier pressure, forcing GWSM to transform. The purpose of this study is: (1) to explore the impact of transformation strategies that are made in the face of current environment on GWSM's operation performance; (2) to explore how GWSM can realize sustainable development from the perspectives of the then or former operators and suppliers; (3) to explore how to adapt its business model and even make pre-deployment for the changing time and current social forms; (4) to make suggestions based on research conclusion on future 
transformation and operation development and on how to ensure sustainable operation for the reference of relevant organizations.

\section{Literature Review}

\subsection{Business Model and Service Types of GWSM}

A business model is a method or means to describe how an organization creates, delivers and captures value. Enterprises should not only consider what the target consumers want to accomplish, but also further consider what roles they should play in dealing with the target customers and their relationship with consumers. Today's competition among enterprises is not only on products, but also on business models (Osterwalder et al., 2010). However, to pursue a price lower than the average market price, GWSM requires the price difference between its products and the same items on the market should be no less than $10 \%$. The price difference is related to the profit of the suppliers and whether the price is in line with the operation purpose of "low price supply". Therefore, it has become the core operation of GWSM to negotiate with the suppliers after setting minimum price.

However, today's operation principles are: (1) If there are the same current items available for comparison, the price difference of the same items shall be referred to; if not, the average purchase price difference of the same items quoted by suppliers shall be referred to. (2) If the price difference quoted by the suppliers is higher than the price difference made by the general welfare office, that quoted by suppliers shall be adopted. (3) If the price difference quoted by the suppliers is higher than that of the current same items, that of the current same items shall be adopted. The price difference is calculated based on the mean of the self-quoted price difference of the registered suppliers of the same item. Compared with the " $20 \%$ reasonable price difference" of the current welfare goods, if the price difference is less than $20 \%$, it shall be calculated as $20 \%$; if it exceeds it, the average price difference quoted by the supplier shall be taken as the common price difference. After the complete procedure of discussing the price and setting the minimum price, the general welfare office shall add $3-5 \%$ gross profit to the purchase price negotiated with the supplier for personnel expenses and related administrative expenses, so that the performance aim of self-financing and balance of payments can be reached (General Welfare Service Ministry of MND R.O.C., 2016). GWSM is a shopping platform that mainly provides its consumers with high-quality and low-cost daily necessities. Therefore, its products are mainly daily necessities. The commodity items are mainly divided into "general products" that are supplied in all regions, including daily necessities, food, textiles, household goods and cultural and recreational goods; "specialized products" that are only supplied in some regions, involving bread and festival products; "fresh food" that includes all kinds of fruits and vegetables, meat, aquatic products, washed eggs, flowers, etc.; and "boutique counters" that are set up with the relevant industries, including counters of boutique clothing, wine, domestic appliances, glasses, and local specialties; In 2017, it opened an online store to keep pace with times by providing consumers with the option of online shopping; In addition, considering Fuji station that GWSM is subordinate to and military station have not issued invoices, it has operated golden Duiduile lottery tickets. Lucky draw, with a maximum bonus of NTD 100,000 , is held every month to draw according to the number of each shopping item (General Welfare Service Ministry of MND R.O.C., 2021).

The Army Welfare Service was originally established to coordinate the supply of non-staple food in the army and welfare goods for officers, soldiers, veterans, and their dependents. Therefore, it is only targeted at nine categories of personnel, including military personnel on active service, teachers and students in military academies, civil servants and employees in the army, veterans (their dependents), reserve soldiers (guidance organization cadres), the first special forces of the army, substitute military service members and the second retired officers and soldiers.

\subsection{Discussion over Relevant Theories of Retail Industry}

\subsection{1 "Authentic" Digital Transformation of Retail Industry}

As the pandemic strikes the world, people's living space is limited, which badly hits physical stores. As the saying goes: "what comes with crisis is opportunity", covid-19 has greatly boosted the growth of digital retail channels, which brought many traditional retailers' opportunities to step into the digital transformation. According to the statistics of the Ministry of Economic Affairs, by February 2020, under the influence of the pandemic, the sales of integrated retail industry have dropped to NTD 91.6 billion, an annual decrease of $9.22 \%$ while in the same period the online sales reached NTD 187.6 billion, an annual increase of $29.22 \%$. What's more, the online sales volume of the same year continued to climb significantly, maintaining the double-digit growth trend (Department of Statistics, Ministry of Economic Affairs R.O.C.). The current situation has made digital transformation a must. However, digital transformation is not only about home distribution, delivery or online 
marketing mode, and it does not simply introduce a certain technology or scientific technologies but aims to optimize the current behavior mode by combining business mode with life process. Based on the previous discussion, how to perfectly integrate the two into the most suitable business model will create "authentic" profit prerequisite for transformation. Recently, KPMG has frequently conducted interviews with consumers of the global retail industry. In order to cope with the "new normal" in the pandemic era, retailers should be equipped with the following five strategies: they should (1) identify their advantages of digital transformation; (2) seek for effective product strategies; (3) improve efficiency with data; (4) strengthen consumer experience; (5) upgrade virtual customer management (Lai, 2020).

One of characteristics of post-pandemic "new normal" is that physical shopping and touching has brought consumers worries and even scares, because of which, their consumption behavior becomes more conservative and cautious. As a result, they impose more serious requirements on retailers or even brands. Retailers must be comprehensive and meticulous to care for consumer experience. They should first satisfy the existed consumers before attracting new one by publicizing the brand online.

\subsubsection{P Theory of Marketing}

The $4 \mathrm{P}$ theory of marketing has been in use for many years. Is it still applicable to today's society? It's unchangeable truth to utilize the marketing strategies to highlight brand value and product characteristics at the right time. However, in the big data era, marketing is not to look for a needle in a haystack but to make the most effective marketing strategies for the target consumers. With the rise of consumer awareness, decision makers should not only think about the products but also view from the consumer side to explore the real demand of consumers, so as to hit the bull's eye of the market. Therefore, when positioning the market, the operators should think from the both sides to identify and fix the consumer pain points and give full play to the product value. Product: a product refers to a good or service you offer to target market. Before selling, please fully understand the characteristics and positioning of your products. Place: it involves all means to deliver a product or service to consumers, including places and delivery. It may involve your offices, places of delivery and other elements like whether the product or service can be bought online. Price: once the product and place are defined, you can start to price. Pricing is not a simple number. It will determine the profit, supply, demand, and market orientation. Promotion: a large number of promotion strategies can be found in the market. In this step, how to let consumers know, understand, like, and buy the product will have impact on the future product, brand awareness and reputation, sales and so on (Kotler and Armstrong, 2017). Promotion is an important element in marketing strategies. Retail industry often employ promotion to spur consumer demands and influence consumer buying behavior. American Marketing Association (AMA) believes that promotion activity is different from the promotion of salesperson, advertisement and public report. It helps to stimulate consumers' purchase and enhance intermediary efficiency. It's an activity about communication, aiming to give impetus to the service, concept or product. For the sellers, promotion is the activity to persuade buyers to accept and use their products or services. For the enterprises, promotion is expected to increase the sales volume so as to raise the revenue. In general, promotion is the general term of all activities that function to stimulate customers to decide to purchase in advance or purchase more in the short term (Kotler and Armstrong, 2017).

The most important purpose of promotion is to influence consumers to make instant purchase behavior. To achieve that, any promotion activity should be as clear and qualified as possible so as to make it easier to assess the promotion accomplishment.

The purpose of promotion has strategic and tactical characteristics. Strategic promotion is a long-term promotion to support the overall competitive strategy of enterprises; tactical promotion is a short-term promotion that can be measured immediately. No matter what kind of promotion purpose, special attention should be paid to the combination of the market positioning and promotion strategies. In general, promotion must reach the three goals: (1) support all salesmen and their promotion work; (2) win the acceptance and cooperation of intermediate agencies for the products (3) boost sales to consumers (Stanley, 1982). Marketing managers should deeply consider the nature and types of target consumers when formulating promotion goals. For consumers who are loyal to the brand, different kinds of plans could be designed to repay them. For consumers who like to change brands, discount coupons and free samples are more effective. The roles promotion plays in marketing include: (1) helping to introduce new products; (2) motivating consumers to try; (3) encouraging consumers to buy again; (4) relieving the promotion impact of competitors; (5) building up consumers' inventory and consumption; (6) strengthening the effectiveness of other promotion tools (Lin, 2020)

\subsubsection{Relationship Marketing}

The concept of relationship marketing originates from industry marketing and organizational marketing. It 
emphasizes how to maintain long-term and interdependent relationships with customers. In recent years, influenced by the change of overall competition environment and rapid development of technology, relationship marketing gradually draws attention of retail industry. It utilizes diversified and customized communicating methods to develop a long-term and mutually beneficial relationship network with a few customers (Kotler and Armstrong, 2017). Berry defined relationship marketing as attracting, maintaining, and enhancing customer relationships by providing multiple services (Berry, 1992). Shain and Chalasani (1992) believed that relationship marketing aims to build one-on-one interaction with customers so that enterprises could conduct cross-selling of the products and build up the interdependence. Therefore, relationship marketing was considered as an integrated aim with the purpose to build and maintain the contact network with particular customers through continuous contact so as to increase the frequency of contact. Rapp and Collins (1990) noted that relationship marketing is a technique to closely connect marketing and service quality with customer loyalty, aiming to help the company to build long-term interaction with customers rather than pursuing the short-term increase of sales. In other words, it hopes to realize the ultimate aim of increasing sales in long run by building long-term relationships with customers and creating brand loyalty. In conclusion, relationship marketing is based on attracting customers and establishing a long-term and mutual trust relationship with them. With the understanding of particular customers, the relationship marketing resorts to database technology to provide them with customized marketing mix so as to build a long-term and mutually beneficial relationship in different degrees, obtain customer loyalty, and form a habitual field. Its implementation should focus on the application of information technology and database whose collection and processing become quicker and more accurate due to the rapid development of technologies. What's more, relationship marketing is more concrete with the help of database. Through the establishment of big data of customers, enterprises can immediately detect the latest environmental changes and grasp the changes of customers' consumption preferences, so that the average actual marketing cost of each customer is reduced. Moreover, they are sharper to expand a market with business opportunities as soon as possible as grasping the changes of customers' demand preferences.

Referring to previous studies, Dwyer et al. (1987) concluded that relationship between sellers and buyers evolves across five stages. The first stage is awareness to make sure whether the other party is a feasible exchange partner. The second stage is exploration, at which the two parties assess the honesty and performance of the other and test whether their goals are consistent. The third stage is exploration, at which the relationship between two parties is strengthened because both are satisfied with the reward and performance of the other. The fourth stage is commitment where the two parties have contractual mechanism and shared values but continue to maintain their relationship. The last stage is dissolution. When one (or both) party evaluates the dissatisfaction with the other party or concludes that the costs of continuation of the relationship outweigh benefits, the relationship is dissolved. This can happen at any time of the relationship development.

\section{Methodology}

\subsection{Interview Subjects}

The study adopted qualitative research by conducting in-depth interview. The interview subjects fell to three categories: (1) GWSM cadres (2) the service recipients of the welfare stations including servicemen, veterans and their dependents (3) GWSM partners. The interview content was based on three main axes (service quality, internal management, and intensive cooperation) to conduct in-depth interviews with the three roles closely related to GWSM. The interview results were summarized and analyzed. What's more, the study analyzed literature related to the key points of the interviews and put forward some suggestions with reference value as the basis for GWSM to make transformation decisions in the future. Generally, the qualitative research is characterized by capturing effective and deep information through focusing on a few samples (Wan, 2004). The interview subjects were sampled from current cadres of management office, servicemen, their dependents, and senior partners. Eight interviewees were involved in the study, including four GWSM cadres, two consumers of the welfare stations and two GWSM partners. The study absorbed the opinions on cognitive differences of communication culture and roles.

\subsection{Design of In-depth Interview Content}

The study aims to explore how GWSM could transform its business model effectively through in-depth interviews and analysis of successful cases so as to make the marketing strategies more suitable to the current trend and consumer behavior mode and the strategies that can guarantee the product quality and profit of suppliers, building a new pattern that benefits GWSM, consumers, and suppliers. The main axes of the interview content have different focuses for different objects. Axis 1: for managers, the question is the impact of transformation strategies on operation performance. For consumers, the question is the views and feelings on the 
change of transformation; Axis 2: for managers, the question is about the business model most suitable to the times made according to sustainable business development policies and four requirements. Due to "low-price supply" policy of GWSM, suppliers can only get the bidding opportunity by reducing the profit margin. What's worse, GWSM's quality control increases the operation cost. However, suppliers are the source of the products and indispensable part of the sustainable development. Therefore, for suppliers, the question is how to make regulations that can benefit many as. Axis 3: for managers, the interview is about the complexity of management for the expansion of the consumer group. For consumers, the interview is about the price which is the main factor influencing the purchase as the consumption habits become younger, service and goods quality, and so on that the group would examine GWSM.

\subsection{Time Procedure of In-depth Interview}

The duration of study lasted from May to April, 2021. To protect the study rights of interviewees, detailed information of the study has been illustrated before the interview, which was conducted with consent. The safety of the recorded data was guaranteed to make sure the interview went smoothly. In regard of different interview subjects and the fact that interviewees may not be familiar with GWSM, before the interview, the study has arranged 25 minutes to make relevant explanation, including the brief introduction, status quo, future development strategies and so on. The interview adopted semi-structured interview that required more time compared with questionnaire. Generally, the default reasonable duration is around one hour so as to minimize the fatigue of interviewers and interviewees.

\section{Analysis and Results}

\subsection{SWOT Analysis of GWSM}

1. Strengths

[1] Tax exemption system: When it was first founded, GWSM had special functions and contributions in helping the government to stabilize people's livelihood and prices, increasing government taxes, helping industrial and commercial development and agricultural production and sales, creating employment opportunities, and enhancing the direct welfare services for officers and soldiers. Therefore, it was initially positioned as a non-profit organization. Benefited from the policy of reducing and exempting tax for non-profit organizations, it was exempted from income tax and business tax, which reduced the operating costs.

[2] Security control of the army: as the first key unit in charge of Taiwan's security, concerned with the security of national defense secrets, the Ministry of National Defense only has the welfare stations to supply all kinds of goods to military personnel.

\section{Weaknesses}

[1] Limitation of consumer source: GWSM is designed to serve the officers, soldiers, veterans and dependents of the National Army. Due to the legal norms and the positioning of the unit, the customer source is limited. What's worse, the lack of resources has obstructed the promotion of marketing strategies, which makes it more difficult to develop potential customers.

[2] Shortage of funds: GWSM upholds the aim of "payment balance and self-finance". It supplies value for money to military officers, soldiers and their dependents, which directly increases the welfare of the National Army but decreases the income of the welfare station. In addition, as a public fund organization, its annual budget needs to be approved by the government units. As a result, the available funds shrink. Therefore, it faces huge challenge in digital transformation (construction of big data system, improvement of network access building, etc.).

[3] Poor management of human resources: In the circumstance where human resources are limited, employees are in low motivation because the unit does not have an assessment mechanism.

\section{Opportunities}

[1] Policy support: Since the mercenary system is launched, Taiwan has made great efforts to promote the welfare of National Army so as to attract young people to join the army. GWSM, as the organization specialize in providing welfare goods to the National Army, may be improved with the support of relevant units.

[2] Digital transformation: with the progress of the times and technologies, the wave of digital transformation strikes the retail industry. Making use of the wave to introduce big data analysis, information management and online stores is the business opportunity for GWSM to realize the sustainable operation.

\section{Threats}


[1] Reduction of military resources: affected by the national military service policy and the structural change of demography, the number of soldiers in the National Army dropped accordingly. As a result, the consumers of welfare stations decreased because these soldiers are one of main consumer sources of GWSM.

[2] Competition in retail industry: Taking a comprehensive view of Taiwan's retail industry, PX mart and simple mart are similar to GWSM. However, compared with them, GWSM is far inferior in terms of capital, scale, environment and equipment. Therefore, without the identity of national defense unit, GWSM is not competitive at all.

[3] Talent Cultivation: the employees of GWSM are mainly seniors while the trained young management talents are insufficient. GWSM staff contact consumers in the frontline and are influencers in the new retail trend. Hence, the talent training is indispensable. However, the training is conducted by office directors of the district who take courses taught by managers every half year and are responsible for the training of all employees in the district. In addition, there are no well-equipped supporting measures nor assessment mechanism, which is not conducive to sustainable operation.

\subsection{PEST Analysis of GWSM}

1. Political

[1] Mercenary System of R.O.C.

[2] Tax-reduction-and-exemption policy for non-profit organizations

[3] Three Security Policy

\section{Economic}

[1] The income level of consumers

[2] Inflation rate

3. Social

[1] The change of consumers' shopping behavior

[2] The change of demographic structure

4. Technological

[1] Internet Innovation

[2] The rise of big data technology

\subsection{Analysis of In-depth Interview}

The study explored the feasible transformation plan of GWSM through in-depth qualitative research. It mainly interviewed the current cadres, customers and supplier partners as the source of material analysis. All interviews were conducted in line with academic ethics. According to the status quo and future development, the study organized and summarized the opinions of interviewees, hopefully to lay foundation to the suggestions on future reform. The study categorized policies into four aspects, namely physical policy, digital policy, consumer policy, and managing policy. The categorization is based on materials and the description of interviewees. The study subdivided the categories to design a suitable reform plan through the comprehensive evaluation of the views of the participants. According to the interview results, if the description is in line with the item of the category, the item will earn one point. There are 59 points and 16 items in total, with the mean of 3.68 points. The results showed that 8 items are higher than the average, including improvement of shopping environment, elimination of facilities, big data analysis, e-commerce mechanism, diversified operation, combination of different industries, personnel training and product control. Many respondents prioritized store renovation and equipment replacement over the inherent requirements of stores.

\section{Discussion and Conclusions}

With the full implementation of Mercenary System, improving the welfare work quality is also one important promoting policy, aiming to resonate with officers and soldiers and attract citizens to join the army. GWSM, as the main organization responsible for the welfare work of the national army, plays a core role in planning effective strategies to benefit both itself and the army. Its service stations and military stations are the only national military service organizations that can directly benefit officers, soldiers and their dependents. However, in the face of the changes of the times and competitors in the same industry, it needs to think about how to change business model to meet the shopping demands of the current consumers 
This study took Taiwan GWSM as an empirical object to explore how internal system, cooperation intention with suppliers and service quality influence its transformation. Through in-depth interviews, the study understood and analyzed the opinions of GWSM cadres, customers, and supplier partners on the current and future business model of GWSM. Meanwhile, it discussed the successful cases of transformation, offering suggestions on how to improve management and transform to provide sustainable service for officers and soldiers, veterans, their dependents and so on. In addition, considering the limited resources of GWSM, the proposed suggestions would be based on the results of in-depth qualitative research to plan items according to their urgency, expand gradually, and focus on the items whose scores are higher than the average value.

This paper puts forward the following suggestions on the transformation of GWSM:

1. In terms of the physical image: welfare stations are the only units that consumers directly contact with. And people's senses are directly derived from vision and hearing. Therefore, the appearance of the stations makes the first impression on consumers. However, since operators want to save costs, it's commonly seen that the environment of most welfare stations is dim and messy, and there is no categorization of products, which leads to the rising cost of maintenance of old equipment. Therefore, the renovation of physical stores is the first step of the transformation. Faced with funds shortage, the renovation should be carried out step by step. And the renovation order should be made according to the operating situation of the stations. The renovation plan can even be made by big data analysis so as to achieve maximum benefits.

2. In terms of digital policy: the term "new retail" comes with the development of information technology. Its main idea is to realize accurate marketing through the cross online and offline sales model and big data analysis after integrating all data. GWSM should observe whether it's necessary to introduce digital transformation according to its own situation, stimulate the buying motivation while grasping the customer demand, reduce the cost of suppliers' hoarding, and then improve the revenue of the stations. Building big data analysis system and improving e-commerce mode will be the foundation for the sustainable operation of welfare stations because the population is aging, and online shopping has become inexorable in post-pandemic era.

3. In terms of customer policy: according to the current consumer behavior, price is not a priority. However, the policies of "low price supply" and "direct benefit" adopted by GWSM is not applicable to today's society as well. The factors that influence consumers involve service quality, commodity quality, diversified choices, etc. In conclusion, there are two suggestions on the unit. First, increase the diversity of options by combining different elements, cooperate with suppliers to produce co-branded products, improve the quality and value of military goods, and enhance the cooperation with suppliers; Second, improve service quality through the reform of personnel management

4. In terms of management policy: the management of enterprises is based on "people". Therefore, how to find key talents is also of the uppermost priority. In a talent shortage society, GWSM is not qualified for external recruitment, so it can only train and develop talents by itself. It should offer professional courses regularly to train professional skills and leadership management ability of managers, establish a team of teacher seeds, encourage employees to help and share experience with those in other stations, improve the performance appraisal system, boost service efficiency and increase employee promotion channels.

\section{Acknowledgements}

This research is supported by the National Chin-Yi University of Technology, Taiwan,

R.O.C. (under Project: Discussion on Integrating Industry Experts' Collaborative Teaching, Institutional Visits, and Issue method to Improve Student Learning Outcomes.)

\section{References}

Berry, L. (1983). Relationship marketing. In Berry, L. L., Shostack, G., \& Upah, G. (Eds.), Emerging perspectives of services marketing. (pp. 25-28). Chicago, IL: American Marketing Association.

Department of Statistics, Ministry of Economic Affairs R.O.C. (2021). Sales of wholesale, retail and food services.

Retrieved

from https://www.moea.gov.tw/Mns/dos_e/bulletin/Bulletin_En.aspx?kind=15\&html=1\&menu_id=6745

Dwyer, F., Schurr, P., \& Oh, S. (1987). Developing buyer-seller relationships. Journal of marketing, 51(2), 11-27. https://doi.org/10.2307/1251126

General Welfare Service Ministry of MND R.O.C. (2016). Regulations on the import of welfare products supply by GWSM. Retrieved from https://www.gwsm.gov.tw/download_grid/gwsm_1050007429.doc

General Welfare Service Ministry of MND R.O.C. (2021). Retrieved from https://www.gwsm.gov.tw/ 
Kotler, P., \& Armstrong, G. (2017). Principle of marketing 17th Ed, Pearson Education Inc. Prentice Hall.

Lai, W. (KPMG Taiwan) (2020). Five strategies to start the digital transformation of the retail industry. Retrieved from https:/home.kpmg/tw/zh/home/insights/2020/11/tw-digital-strategy-in-retail-industry.html

Lin, C. (2020). Marketing management (8th ed.). Taipei: Hwa Tai Publishing Co.

Osterwalder, A., Pigneur, Y., Clark, T., \& Smith, A. (2010). Business model generation: A handbook for visionaries, game changers, and challengers. Hoboken, New Jersey: Wiley.

Rapp, S., \& Collins, T. (1990). The great marketing turnaround: The age of the individual and how to profit from it. Englewood Cliffs, NJ: Prentice-Hall.

Shani, D., \& Chalasani, S. (1992). Exploiting niches using relationship marketing. Journal of Consumer Marketing, 9(3), 33-42. https://doi.org/10.1108/07363769210035215

Stanley, R. (1982). Promotion: Advertising, publicity, personal selling, sales promotion. Englewood Cliffs, NJ: Prentice Hall, Inc.

Wan, W. (2004). Application of in-depth interviews in qualitative research. Living Technology Education, 37(4), 17-23. https://doi.org/10.6232/LTE.2004.37(4).4

\section{Copyrights}

Copyright for this article is retained by the author(s), with first publication rights granted to the journal.

This is an open-access article distributed under the terms and conditions of the Creative Commons Attribution license (http://creativecommons.org/licenses/by/4.0/). 